This PDF is a selection from a published volume from the National Bureau of Economic Research

Volume Title: Measuring Wealth and Financial Intermediation and Their Links to the Real Economy

Volume Author/Editor: Charles R. Hulten and Marshall B. Reinsdorf, editors

Series: Studies in Income and Wealth, volume 73

Volume Publisher: University of Chicago Press

Volume ISBN: 0-226-20426-X, 978-0-226-20426-0 (cloth); 978-0-226-20443-7 (eISBN)

Volume URL: http://www.nber.org/books/hult10-1

Conference Date: November 12-13, 2010

Publication Date: January 2015

Chapter Title: Durable Financial Regulation: Monitoring Financial Instruments as a Counterpart to Regulating Financial Institutions

Chapter Author(s): Leonard Nakamura

Chapter URL: http://www.nber.org/chapters/c12521

Chapter pages in book: (p. $67-88)$ 


\title{
Durable Financial Regulation Monitoring Financial Instruments as a Counterpart to Regulating Financial Institutions
}

\author{
Leonard Nakamura
}

\subsection{Introduction: A Financial Regulatory Database for Durable Financial Regulation}

In the wake of the recent financial crisis, an effort is underway to redesign the regulation of financial institutions. As part of the new regulatory structure, a new information framework may be desirable. In particular, I describe a system for monitoring financial instruments as a complement to the regulation of financial institutions. If a system of financial regulation is to be durable, it must evolve with the development of new institutions and instruments. This is one of the chapters in this volume that sets forth perspectives on frameworks for the analysis of systemic risk data collection. Here I discuss explicitly how to construct a macro-micro database that links our knowledge of sectoral financial assets, liabilities, and flows to underlying microdatabases with data on individual instruments and the holdings and liabilities of individual economic actors (households, firms, states). This database represents one way to implement the Squam Lake proposal for

Leonard Nakamura is vice president and economist at the Federal Reserve Bank of Philadelphia.

The views expressed here are those of the author and do not necessarily reflect those of the Federal Reserve Bank of Philadelphia or the Federal Reserve System. I would like to thank Viral Acharya, John Bell, Mitchell Berlin, Robert Bliss, John Bottega, Paul Calem, Satyajit Chatterjee, Larry Cordell, Ronel Elul, Jose Fillat, Jeff Fuhrer, Josh Gallin, Itay Goldstein, Chris Henderson, Chuck Hulten, Bob Hunt, Tor Jacobson, George Kauffman, Arthur Kennickell, Bill Lang, Jamie McAndrews, Susan McIntosh, Greg Nini, Marshall Reinsdorf, Kasper Roszbach, Tom Stark, Todd Vermilyea, Larry Wall, Christina Wang, two anonymous referees and participants in seminars at the Sveriges Riksbank and at the Federal Reserve Banks of Boston, New York, and Philadelphia, the Federal Reserve System Conference on Real-Time Policy Issues, and the System Committee on Financial Structure and Regulation for many helpful comments. For acknowledgments, sources of research support, and disclosure of the author's material financial relationships, if any, please see http://www.nber.org/chapters/c12521.ack. 
a new information infrastructure for financial markets (French et al. 2010, chapter 3).

What is meant by such a macro-micro financial instrument database? The macro side of the database would have summary aggregate data on the nominal quantities of financial instruments and both the debtors and the current asset holders, by broad sector. I argue that this macro side is best understood as an extension of the Flow of Funds database already collected by the US Federal Reserve. The micro side of the database would have microdata samples of individual instruments and economic actors. The two sides of the database could then be interconnected so that the microdata can be interpreted as a (possibly weighted) sample of portions of the aggregates. The proposed macro-micro database would make it possible to detect, understand, and mitigate potential systemic risks.

In the 2007-2009 financial crisis, financial regulators were surprised both by the size of the potential losses and by the types of institutions that were affected. Regulators moved to protect investment banks, insurance companies, mutual funds, and government-sponsored enterprises, as well as traditional depository institutions. More detailed knowledge of the risks of financial instruments and the holders of these risks might have permitted regulators to move more aggressively in advance of the crisis and would have made regulators better informed once the crisis was at hand. I examine some of the risks that arose in the recent crisis and how we could have known more about them as they were beginning.

The database I describe is intended to be of substantial use to supervisors in identifying risk at regulated institutions. It would also be used to help them know when financial risks are being held by unregulated financial institutions, generating new systemic risks. United States and European regulators are already taking steps to improve data availability. The Eichner, Kohn, and Palumbo (chapter 2, this volume) argues that while macrodata may be useful for discerning trends in financial risks, it is valuable to have more specialized information to further illuminate them. My framework would take a step toward facilitating this side-by-side use of macro- and more specialized data.

An important consideration in any such database is that it create a costeffective means of collecting and organizing the microdata, that is, the individual financial instruments, so that the evolution of the underlying risks can be followed. For this reason we consider how to best use and improve existing databases, as well as how to develop new ones. Just as the Flow of Funds Accounts permits us to observe how much the sectors own and owe by broad class of instruments, we also need links across the microdatabases that help us observe the distribution of individuals, firms, and agencies that own and owe, by individual instruments.

In this chapter I set forth a framework in which a US financial data office could be the central data keeper for information on US-originated financial 
instruments and could be active in making the data available to academic researchers as well as economists from regulatory agencies. Such an office has been provided for in the Dodd-Frank Act as the Office of Financial Research (OFR). The OFR would actively share data (within the limits of confidentiality) and research results on the risks of specific financial instruments with financial regulators, with risk managers within financial institutions, and with the academic community. It would thus strengthen financial institutions' ability to recognize and manage their own risk, conceivably reducing the burden on regulation.

The framework that I set forth here does not easily encompass crossborder risks. However, if foreign financial supervisory authorities set up similar frameworks in their jurisdictions, and if data can be shared among international supervisors, then some cross-border risks may be assimilated into a global framework. The paper by Cecchetti, Fender, and McGuire (2010) discusses the Bank for International Settlements (BIS) data and how the BIS's global financial statistics may be used as a framework for monitoring cross-border risks, using the prime example of the carry trade, which may increase volatility across international borders.

The chapter by Eichner, Kohn, and Palumbo, like this one, explores the development of both macro- and microanalyses of data. They argue, as I do, that during the recent financial crisis regulators lacked crucial disaggregated information about the changing risks in household balance sheets amid weakening underwriting standards. Their paper points to the observational paradox that is a central problem for regulation: that the problems that regulators are aware of are those that they place limitations on. Financial activity then naturally flows away from the known risks toward risks that are unknown to the regulators. Maintaining financial stability may then depend on how quickly regulators can inform themselves about the risks of new activities. By pursuing a variety of targeted microanalyses at the same time as macro indicators of risk, there is a greater likelihood that regulators can limit the damage from new risks created by the inevitable evolution of the financial system.

\subsection{How Monitoring Financial Instruments Can Aid in the Regulation of Financial Institutions}

The task I am describing has two central pieces: one is finding out who holds financial instruments and the other is measuring the risks of the instruments and of the holders. Before addressing precisely how these objectives could be achieved, let us use examples from the 2007-2009 financial crisis to consider further how this informational database will aid the systemic regulator and all financial regulators.

In this part, we make several points: (1) the database could aid in detecting buildups of systemic risk outside the regulated financial system; (2) it 
could reduce the opacity of institutional portfolios; (3) it could support studies of the changing risks of instruments, in particular, by permitting investigation of the actions of agents along the full life cycle of instrument creation, distribution, and servicing; (4) it could support pricing analysis that would bring financial, economic, and econometric theory to bear in the determination of potential systemic risk; (5) it could engage a broader, more creative, and potentially more objective community in systemic risk analysis; (6) it could enable regulators to observe counterparty risk and to undertake regular systemic stress testing; and (7) it could be used to improve estimation of long-term relationships across variables that may be useful in identifying potential asset bubbles.

Following the risk off-balance sheet. The US financial institutions are regulated piecemeal. This system avoids excessive concentration of regulatory power and provides avenues of regulatory competition: regulators who regulate efficiently can be rewarded. However, the system has weaknesses. One is that regulated financial entities may shop for weak regulators and, by choosing the most complaisant regulator, weaken the system as a whole. Another is that financial activities and instruments may be created or moved outside the purview of regulation.

A financial asset such as a mortgage can be created within a tightly regulated financial entity, such as a commercial bank, or a loosely regulated one, such as a mortgage subsidiary or a freestanding mortgage company. The regulatory treatment of the mortgage may depend on the form in which it is held. For example, the AAA tranche of a collateralized debt obligation may have much lower regulatory capital requirements than a mortgage loan held in portfolio. Depending on the relevant costs and benefits of the regulatory treatments and the risks of the assets, the form in which the asset is held may change, and this form may have little to do with underlying economic efficiency.

A mortgage asset can be moved off the originator's balance sheet by placing it in a separate legal entity, such as a special investment vehicle or an entity that issues asset-backed commercial paper. This vehicle may reproduce the characteristics of a financial intermediary, by issuing short-term liabilities that are money-like while it holds long-term instruments that are subject to some risk. These entities generally have standby lines of credit issued by the financial intermediary. If the entity's asset risk increases, the holders of its short-term liabilities may refuse to roll over the debt, creating a run on the entity and a drawdown on the standby line of credit. Thus, the risks from the vehicle can be easily transferred to the financial intermediary, while the capital of the financial intermediary may be inadequate, since these assets and liabilities were not on its books. The risks and consequences of asset-backed commercial paper are documented in Covitz et al. (2013).

This and other examples of the creation of a "shadow banking" system point out the value to financial regulators of continuing to monitor financial 
assets after they are removed from the balance sheets of closely regulated financial intermediaries. Note that such a system would permit innovationit would not block new institutions or new instruments from arising. Rather, it would seek to monitor these novelties and perhaps bring them under regulation if they reach systemic importance.

As the case of AIG illustrates, the migration of systemic risk to a lightly regulated or unregulated entity contains the seeds of systemic financial crisis. To contain the 2007-2009 financial crisis, the regulatory process would have had to identify that AIG was a systemic risk, ascertain the quantitative scale of those risks, and bring AIG under greater regulatory discipline, including preparing a means for unwinding AIG with minimal systemic risk.

In their article on the central role of the repo market in the recent financial crisis, Gorton and Metrick (2012) are able to analyze the risks to that market posed by lightly regulated and unregulated cash pools and highlight the danger of regulators relying exclusively on data from regulated institutions. Adrian et al. (2014) discuss the mechanics of the market and data needs for adequate monitoring.

Opacity. An important aspect of the recent financial crisis was that many financial institutions themselves lost track of the total real estate exposure of their portfolios. This reflected, in part, the fact that regulation created incentives for opacity. To reduce capital requirements, an institution may change an instrument from a loan to one or more securities that it continues to hold, although no risk has been transferred. The resulting increase in opacity may cause an institution to lose track of its true vulnerabilities.

If financial instruments are opaque to the financial institution holding them, then they must be even more opaque to a regulator. To the extent that instruments can be finely categorized and characterized, and their risks more precisely measured, both regulators and internal risk monitors at financial institutions will be better able to avoid crises. Steps to reduce opacity are being taken to the extent that customized instruments that are not exchange traded will have higher risk capital requirements. To the extent that instruments are exchange traded, they will be easier to categorize and quantify, and measuring their risk will be easier.

To the extent that financial instruments and securities based on them are priced on exchanges, similar customized instruments and securities may be evaluated and priced based on a model of the values of their financial characteristics. When trades or acquisitions of such assets are observed, the quality of the mark-to-model pricing may be verified.

Derivative trading is also being made more transparent through creating risk penalties for derivaties that are not exchange traded. Derivatives are another avenue for both opacity and for transfer of risk; Acharya (2014) discusses the value of regulatory and public disclosure of derivative trading.

Following the full life cycle of instrument creation, distribution, and servic- 
ing. There are many facets to the creation and maintenance of financial instruments. The characteristics of the financial instrument may be influenced by many institutions and agents. Actions of one set of agents may affect instruments so as to exacerbate systemic vulnerabilities. In the losses associated with the recent financial crisis, the actions of a panoply of agents were at work in increasing the risk of mortgages. The severity of the risks of real estate finance might have been recognized earlier if regulators had been more aware of changes taking place across a variety of institutions.

The risks of mortgages were compounded because a number of the agents were subject to uncorrected weaknesses, many of them well recognized by relevant players. For example, persistent and significant upward bias in home appraisals was recognized as early as the mid-1990s (Cho and Megbolugbe 1996). According to this analysis, some 95 percent of home purchase mortgages in the Fannie Mae mortgage database had appraisals at or above the sale price. Having been recognized, this bias was tracked through automated valuation models (AVMs) by Fannie Mae and Freddie Mac. It was well known among those actively using these AVMs that these biases were particularly strong for refinancing and for subprime lending. However, these biases were not widely known or understood outside this circle. In particular, many regulators were not aware of the risks thereby posed to mortgage refinancing, since upward appraisal bias resulted in understated loan-to-value ratios.

Upward biases in refinance appraisals would have the consequence of allowing homeowners to refinance with too small a cushion against the risk of home price decline. Unfortunately, the databases of the governmentsponsored enterprises have not been available for study by academics; their information has been considered the intellectual property of these entities. The losses at these entities - which perhaps might have been mitigated if scholars and regulators had had better access to these databases - have far exceeded the value of the intellectual property of these entities. Moreover, it is by no means obvious that these entities should have exclusive rights to the data generated by government sponsorship.

Microdata have been used to analyze changes in subprime mortgage lending standards (Demyanyk and Van Hemert 2011; Brueckner, Calem, and Nakamura 2012), the behavior of securitizers (Elul 2009), and the behavior of mortgage brokers (Garmaise 2008; Keys et al. 2009).

Demyanyk and Van Hemert (2011) found that subprime mortgage lending standards - as measured ex post by delinquencies and foreclosuresdeteriorated monotonically from 2001 to 2006 . The decline in lending standards is revealed in differential performance rates detectable within a year of origination. However, aggregate default rates were somewhat masked by the rise of housing prices from 2003 to 2005 . Brueckner, Calem, and Nakamura (2012) show that house price inflation momentum tended to drive the decline in lending standards in a vicious cycle in which house price inflation 
reduced the risk to mortgage lenders, who then reduced lending standards at the local level, and thus widened the effective demand for housing and further inflated house prices.

Elul (2009) finds that prime mortgage loans that were securitized were of lower quality than loans that were held in portfolio. He does not find a similar effect for subprime loans, but the vast majority of subprime loans were intended for securitization.

Garmaise (2008) presents evidence that mortgage brokers' lending standards deteriorated over time so that experienced mortgage brokers' loans performed worse. Keys et al. (2009) show that states with stricter regulation of mortgage brokers had better performing subprime loans.

We use these examples to illustrate the types of data that could have permitted regulators to detect changes in the risks of mortgages. That, in turn, we are arguing, could have resulted in an earlier and more appropriately calibrated response to the impending crisis.

Financial regulators and academic financial researchers are now assembling microdata sets for forensic reasons, to attempt to understand the causes, consequences, and the scale of the financial crisis. However, it is widely recognized that the data collected to date have serious weaknesses. In particular, commercial databases often have crucial identifiers missing or encoded so that associating observations across data sets has been difficult or impossible. In addition, financial institutions, servicers, and other parties whom the systemic regulator needs to be able to identify are often contractually anonymous within these databases. Permitting the database to obtain these identifiers may require regulatory action or possibly legislation.

In addition, certain agency problems appear to have worsened significantly as time passed. The rise of mortgages with very high combined (reported) loan-to-value ratios (100 percent or higher) was another warning sign of difficulties. These data were partially available in, for example, LoanPerformance microdata sets on second mortgages based on information gathered from mortgage servicers. But it was often difficult for the holders of first mortgage portfolios to know the extent to which second liens had made their mortgage assets riskier.

Systemic risk pricing in the market. Economic theory suggests that financial payoffs that will occur when the marginal utility of consumption is high have a greater present value than payoffs in periods when the marginal utility of consumption is low. Systemic risks involve low payoffs in bad economic states, when the marginal utility of consumption is high. Instruments with embedded systemic risks thus have lower value and require compensatingly higher rates of return in equilibrium.

Coval et al. (2009b) have pointed out that structured finance created strong incentives to concentrate systemic risks in financial instruments that otherwise were of very low risk. These financial instruments had inherently high expected returns because of the risks involved. As long as the systemic risks 
did not emerge, such instruments had a high rate of return and appeared to be earning excess returns. Coval et al. (2009a) then go on to develop a pricing kernel for structured finance instruments that have little idiosyncratic risk but high systemic risk and argue that, in fact, such economic catastrophe bonds that were issued in the period just before the financial crisis were overpriced. In this case, bonds appeared to be paying a high rate of return and thus represented a financial arbitrage opportunity with positive excess return, but in fact, they had a negative excess return and were fundamentally loss making to the holders.

These two papers show how data on financial instruments can reveal the existence of systemic risk and may be of help to regulators in requiring the holders of such assets to hold higher capital, offsetting the apparent reward to holding these assets. To the extent that the systemic regulator is held responsible for minimizing the likelihood of a systemic crisis, a paradox arises. As the likelihood of systemic risk declines, the price of holding the systemic risk will fall. This in turn encourages the creation of more instruments of this type, until a systemic crisis does occur. The consequence may be that the crisis, when it occurs, may be surprisingly large. Maintaining a watch over this potential dynamic will be an important task of the systemic regulator.

Engaging a broader and more objective community in monitoring. To the extent consistent with privacy considerations, permitting academics and investment advisors to access and analyze the financial database would enhance the capacity to identify cyclic and systemic risks within the US financial structure.

This broader community can bring new insights from financial research to bear on these issues and also offer a counterweight to the authority of the private financial institutions. One of the difficulties regulators have faced in the recent period is that employees at private financial institutions have been compensated on a scale with which public authorities cannot hope to compete. While higher compensation may not strictly imply higher marginal product, the possibility that it does so may cause less-well-paid regulators to sometimes defer to the judgment of extremely well-paid regulatees. (Indeed, part of the Basel II structure was constructed on the assumption that complex financial institutions were better positioned to measure their own risks compared with outside regulators.)

Moreover, internal risk managers are often in a similarly weak position, as risk management is a cost center, while the departments creating the risks are profit centers that can richly reward their employees. The regulatory database can provide empirical models of risk that enable bank supervisors and internal risk managers to more aggressively challenge the views of risk takers.

By opening up the measurement of risk in the financial database to a wider group, regulatory risk measurement can be done at the frontier of 
financial science. Indeed, the systemic regulator could have built into its structure a research steering group composed of leading academic experts, as well as funding for grants and conferences to identify the structure of risks underlying the database. In addition, if the systemic regulator should hire a full-time staff of research economists to undertake financial risk studies, this might well help in identifying data shortcomings, as these researchers would gain privileged, hands-on views of the data. If that knowledge can be freely shared with regulators, the regulators could ask the financial institutions originating the data to improve their data management processes as needed.

One potentially important first research task of the systemic regulator could be a full quantitative accounting of the sources of the financial crisis. One possibility would be to set up a contest for the best paper providing such a full quantitative accounting, to be judged by a prestigious academic panel with the reward being a substantial sum (say, $\$ 1$ million). The academic panel could also be charged with assessing the weaknesses of the best paper, and additional, smaller awards would be given to subsequent papers that eliminated these shortcomings.

Counterparty risk and systemic stress testing. Simulating the impact of systemic risks on the financial system would be greatly facilitated by a clear view of which financial institutions are holding which financial instruments.

In a financial crisis, the identification of counterparty exposure comes to the fore. However, in the current complex financial environment, counterparty exposure has become far from transparent. Large complex financial institutions have hundreds, even thousands, of subsidiary institutions. Thus, in the recent crisis, financial institutions considering the possibility of a default by some threatened bankruptcy were unable to accurately estimate the size of their exposures. This is a problem that large financial institutions are now very aware of, and steps are being taken to link subsidiaries to their parents through institutional identifiers. A unique registry of legal entity identifiers is in the process of being adopted internationally-these will permit regulators and financial entities to identify the parties to a transaction with much greater certainty. ${ }^{1}$

More broadly, while tools for mapping the dynamic conditional correlations across financial instruments are being rapidly developed (e.g., Engle 2009), these correlations are being traced out by trades made by agents who themselves typically lack detailed knowledge of the dynamic interrelations of financial institutions. An important task of the systemic regulator will be to understand the volatile pattern of institutional relationships, as they are revealed in quarterly or daily snapshots of institutional cross-exposure.

Addressing bubble-like risks. The identification of financial bubbles remains a difficult art. It is often impossible to clearly identify a bubble in 
advance. While we can identify key historical ratios between measures of price and measures of return, for example, and historical mean-reverting relationships, it is very difficult to be sure that a structural change has not occurred. However, it is relatively easy to model the possibility that a bubble has been created and the consequences of the bubble bursting; that is, we can assume that historical averages will be maintained and that reversion to the mean occurs over some short period of time. For housing, ratios of rents to house prices appear to display a long-run equilibrium relationship that can be and was used to scale the likely size of the mean reversion - a relationship documented by Gallin (2008) and by Crone, Nakamura, and Voith (2010). We can then perform stress simulations under such scenarios using the database. These simulations could then be brought to the relevant financial regulators and internal risk monitors, and perhaps to Congress, if additional statutory authority appears necessary.

Such simulations are instructive stress tests in that the case of no structural change is hard to rule out, so placing very low weight on this case is generally unconvincing. In addition, outside researchers could be allowed to (or be paid to) conduct their own simulations, offering useful alternative scenarios to regulators.

\subsection{Expanding the Flow of Funds Framework: The Macro Side of the Database}

The macro side of the database helps regulators know, for example, which types of financial institutions are funding a given financial instrument. Because the totality of such transactions is so vast and variegated, it is vital to have an intellectual framework for organizing and aggregating them. I argue that the Flow of Funds Accounts provide such an intellectual framework. ${ }^{2}$ Eichner, Kohn, and Palumbo (chapter 2 ) argue a similar point about the US-SNA, the overarching framework that encompasses the Flow of Funds and the National Income and Product Accounts.

How can we use the Flow of Funds Accounts as a framework for the envisioned database? Most fundamentally, the Flow of Funds Accounts provides an accounting framework that includes all the assets and liabilities of nonfinancial and financial institutions. The Flow of Funds (a part of the system of financial accounts that is compiled by the Federal Reserve System) establishes a framework that accounts for the financial assets and liabilities of all US parties (including households, nonprofits, firms, governments, and the rest of the world). ${ }^{3}$ Furthermore, the Flow of Funds has a

2. An online guide to the Flow of Funds Accounts can be found at http://www.federalreserve .gov/apps/fof/. Additional detail on the housing finance accounts can be found at http://www .federalreserve.gov/releases/z1/about/kennedy-fof-20120628.pdf.

3. For a description of the Flow of Funds and its relationship to the national accounts, see Bond et al. (2007). Further discussion is in Teplin et al. (2006) and in Yamashita (2013). 
fluid conceptual framework that can be expanded to reflect derivative and synthetic instruments. The US Flow of Funds is tied to the US National Accounts; individual sectors borrow and lend because of the national, sectoral, and individual imbalances between saving and investment. To the extent that financial instrument risk is tied to agents, sectors, and markets, this framework facilitates the economic analysis of risk.

Similar to the national income accounts, the Flow of Funds Accounts framework can accommodate a series of satellite accounts to extend the value of the framework. These, some of which are discussed below, could include mark-to-market or mark-to-model pricing, agents behind the scenes (such as exchanges and rating agencies), and measures of risk. Finally, the microdatabases and statistics that underlie the aggregate measures could be associated with the Flow of Funds as a linked library, in which the aggregate categories of the Flow of Funds organize the microdata as a set of reference headings.

The US Flow of Funds Accounts has two intimately related parts. One part is a set of flows representing net new borrowing and lending, and the other is a set of outstanding stocks of assets and liabilities. ${ }^{4}$ These are presented as aggregates by sector (lenders and borrowers, such as banks, households, governments, and corporations) and by instrument (equity, mortgages, loans, commercial paper, consumer credit, and securities).

The Flow of Funds reflect the financial assets and liabilities and the financial activities of both financial and nonfinancial entities in the United States. It thus provides a natural framework from which a systemic regulator could observe the types of risks distributed across the financial system.

The first column in table 3.1 shows the credit market borrowing by nonfinancial sectors in 2008, taken from the Flow of Funds, Annual Flows, as published June 11, 2009. In this table, borrowings are organized by instrument, such as commercial paper and home mortgages, and by sector, such as household sector and nonfinancial corporate business. The table also shows borrowings by foreigners. The second and third columns show the debt levels owed by the nonfinancial sectors for the same instruments and sectors at year-end 2007 and 2008. Adding column one to column two gives column three; the net borrowing flow during 2008 added to the level of debt at the end of 2007 gives the level of debt at the end of 2008. Other summary tables in the Flow of Funds Accounts, not presented here, show financial sector borrowing and total liabilities and their relationship to total financial assets. Yet others relate the Flow of Funds to national savings and investment and the national income accounts.

4. The quarterly net flows are defined to be the difference in the quarterly level of outstanding stocks. In practice, however, the Flow of Funds Accounts levels are not always consistent and contain breaks resulting from incomplete or inconsistent underlying data. When there is a break, the quarterly flow is defined as the flow associated with a consistently defined level and may not be equal to the reported difference between quarterly levels. 
Table 3.1

Credit market borrowing and debt owed by nonfinancial sectors, 2007 and 2008 (billions of dollars)

\begin{tabular}{|c|c|c|c|}
\hline $\begin{array}{l}\text { Annual flows and levels } \\
\text { Tables F.2 and L.2 }\end{array}$ & $\begin{array}{l}\text { (1) Net borrowing } \\
2008\end{array}$ & $\begin{array}{l}\text { (2) Year-end debt } \\
2007\end{array}$ & $\begin{array}{l}\text { (3) Year-end debt } \\
2008\end{array}$ \\
\hline Domestic & $1,873.2$ & $31,707.1$ & $33,580.3$ \\
\hline By instrument & $1,873.2$ & $31,707.1$ & $33,580.3$ \\
\hline Commercial paper & 7.7 & 123.8 & 131.5 \\
\hline Treasury securities & $1,239.0$ & $5,099.2$ & $6,338.2$ \\
\hline Agency and GSE-backed securities & 0.2 & 23.1 & 23.3 \\
\hline Municipal securities & 63.2 & $2,618.9$ & $2,682.1$ \\
\hline Corporate bonds & 204.6 & $3,558.9$ & $3,763.5$ \\
\hline Bank loans, n.e.c. & 195.2 & $1,648.9$ & $1,844.1$ \\
\hline Other loans and advances & 62.0 & $1,674.5$ & $1,736.6$ \\
\hline Mortgages & 57.3 & $14,407.8$ & $14,465.1$ \\
\hline Home & -109.0 & $11,137.2$ & $11,036.6$ \\
\hline Multifamily residential & 53.8 & 820.0 & 878.2 \\
\hline Commercial & 109.3 & $2,342.8$ & $2,439.2$ \\
\hline Farm & 3.3 & 107.8 & 111.1 \\
\hline Consumer Credit & 44.0 & $2,551.9$ & $2,595.9$ \\
\hline By sector & $1,873.2$ & $31,707.1$ & $33,580.3$ \\
\hline Household sector & 49.5 & $13,778.4$ & $13,832.9$ \\
\hline Nonfinancial business & 544.1 & $10,614.5$ & $11,153.7$ \\
\hline Corporate & 362.6 & $6,809.3$ & $7,167.0$ \\
\hline Nonfarm, noncorporate & 170.2 & $3,591.2$ & $3,761.4$ \\
\hline Farm & 11.3 & 214.0 & 225.3 \\
\hline State and local government & 40.4 & $2,191.8$ & $2,232.2$ \\
\hline Federal government & $1,239.2$ & $5,122.3$ & $6,361.5$ \\
\hline $\begin{array}{l}\text { Foreign credit market debt held in } \\
\text { United States }\end{array}$ & -152.1 & $2,017.3$ & $1,864.9$ \\
\hline Commercial paper & -71.0 & 413.0 & 342.0 \\
\hline Bonds & -84.7 & $1,478.1$ & $1,393.4$ \\
\hline Bank loans n.e.c. & 5.1 & 102.8 & 107.9 \\
\hline Other loans and advances & -1.6 & 23.4 & 21.5 \\
\hline Domestic and foreign & $1,721.1$ & $33,724.4$ & $35,445.2$ \\
\hline
\end{tabular}

Through its ties to the National Income and Product Accounts, the Flow of Funds Accounts obtain a benchmark measure of the total borrowing and lending by a given sector necessary to balance net cash flows. This provides an indirect estimate of the completeness of direct measures of total borrowing and lending.

The efficiency of the borrowing and lending of the nonfinancial sector provides a prime economic rationale for the activities of the financial sector. An important rationale for systemic regulation is to ensure this two-way flow of financial transactions. It is of fundamental importance that the financial transactions of the nonfinancial sector come under the scrutiny of the systemic regulator. Table 3.1 presents a compact view of the total borrowing of the nonfinancial sector from the Flow of Funds Accounts, year-end 2007 and 2008 . 
Less aggregated tables in the Flow of Funds - as of this writing there are thirty-one sector tables and thirty-one instrument tables - show holdings of instruments by different sectors. In short, the Flow of Funds relates instruments to the assets and liabilities of institutions. The assets and liabilities of each individual agent are naturally organized within this flow of funds framework. Moreover, the databases in which samples or the universe of agent outstandings or flows are captured naturally map into this framework as well. For example, if an agency is using samples of a credit bureau's data on individuals and households, this database can be mapped into and benchmarked with the household balance sheet from the Flow of Funds Accounts.

\subsection{What the Existing US Flow of Funds Accounts Lack: Creating an Expanded Framework with Satellite Accounts}

In many cases, the existing US Flow of Funds Accounts lack crucial detail that would have been helpful to know during the financial crisis. For example, an important question was: Which sectors were holding the nonagency jumbo and subprime securitized mortgages? The table on residential mortgages does have an entry that shows the total quantity of home mortgages that were the assets of ABS issuers - nonagency pools of \$2.2 trillion in 2007 (table L.218). However, the table on Issuers of AssetBacked Securities (L.124) lists their assets as \$4.5 trillion (including credit cards, commercial mortgages, and agency and GSE-backed securities) and lists liabilities divided into commercial paper ( $\$ 0.6$ trillion) and corporate bonds ( $\$ 3.9$ trillion). Corporate bonds are also in table L.212, Corporate and Foreign Bonds, which shows the holders of $\$ 11.4$ trillion of bonds, of which \$2.2 trillion are nonagency ABS. There, we can find the various sectors that hold corporate and foreign bonds, but we do not know which sectors are holding nonagency ABS. One significant exception is the account for US-chartered commercial banks, which divides corporate and foreign bonds into (1) private mortgage pass-through securities, (2) CMOs and other structured MBS, and (3) other. This allows us to see that banks and thrifts were holding about one-quarter of the nonagency ABS, while they held only 10 percent of other corporate and foreign bonds. But the other nonagency ABS holders could not be easily identified from the Flow of Funds Accounts, so it was difficult for regulators to estimate whether other holders of nonagency ABS posed a threat to financial stability - as it turned out, they did.

Satellite Accounts. National income accounts can be expanded in ways that may not easily be accommodated into the complete framework. For example, if quarterly data are not available for a set of statistics, or if, say, prices are not available, then a satellite account can be created. Similarly, it would be useful for an expanded macro-micro financial database to have a number of satellite accounts.

Net financial flows could be further decomposed into the sum of gross 
new originations, repayments, defaults, and revaluations, but these subelements are not shown separately within the Flow of Funds Accounts. ${ }^{5}$ From a regulatory perspective, it would be preferable to track these subcomponents, particularly for longer-term debt. Doing so would facilitate tracking instruments by vintage and would also contribute to data quality. It would also help macroprudential supervisors, for example, to see to what extent nonfinancial balance sheets are being repaired through saving and to what extent through defaults. Gross flows may be tracked by and matched with microdata sets on loan originations, including regulatory data sets such as the Home Mortgage Disclosure Act (HMDA) data, financial industry data such as Fannie Mae and Freddie Mac data sets on agency securitizations or daily data on market transactions, and data collected by statistical agencies.

The aggregate stocks and the US Flow of Funds assets and liabilities could be matched with microdata on households (credit bureau, statistical agencies, regulatory data) and firms (Compustat, call reports, statistical agencies, SEC filings, Survey of Terms of Bank Lending). The matching of the aggregate statistics with historical and current microdata would permit regulators to examine the default risks associated with financial instruments as they evolve. Having measured variances and covariances of financial instruments, the systemic regulator can use the augmented Flow of Funds to identify the sectors in which the risks associated with the financial instruments are lodged. In turn, the microdata will aid the systemic regulator in examining the sectors and observing the distribution of risks across financial firms.

Another important satellite account would have prices. The national accounts framework can accommodate valuation changes, but the US National Income Accounts, by their very nature, capture flows of production and not capital gains. Similarly, the US Flow of Funds Accounts primarily carries assets and liabilities at nominal book value. For risk analysis, it is highly desirable to have the mark-to-market prices for exchange-traded instruments. It would also be useful to be able to mark-to-model instruments that are not frequently traded.

It is crucial for the systemic regulator to have a broad picture of the risks of the set of financial instruments and their consequences for the system of financial institutions. To support the database, one aspect of the new regulatory structure could be a requirement that financial institutions - regardless of their direct regulator-provide information to the systemic regulator to facilitate construction of the database. Indeed, the regulatory structure should have the provision of such information as part of the transparency requirement of all financial regulation. One example of missing data is the

5. Morris Mendelson (1962) and Edward Denison (1962) provide some useful early discussion of the difficulties and value of decomposing net flows in the Flow of Funds Accounts. 
portfolios of hedge funds; these are not shown in the Flow of Funds separately because of a lack of data and are implicitly included in households.

The US (and the worldwide) financial system is in constant flux due to innovations in the world economy and to financial innovations. Undeniably, many of these financial innovations have reduced the transactions and information costs associated with borrowing and lending and thus have improved the efficiency of consumption and investment. However, financial market participants, left to pursue their private interests, will not take fully into account the knock-on effects of their actions on others. In particular, financial markets include both sophisticated and unsophisticated borrowers and lenders and informed and uninformed borrowers and lenders. The information asymmetries have their beneficial aspect - it is valuable to have specialization. But financial agents may be tempted to use these information asymmetries for private, inefficient gain. ${ }^{6}$ This is the motivation for regulation, which creates an ongoing temptation to escape regulatory burden. Profit-maximizing financial innovation can create socially desirable efficiencies, or it can be a socially undesirable means of evading regulatory constraints.

Financial regulators are typically called on to regulate financial institutions that are the sites of existing financial activity. New financial instruments and institutions may evolve outside the scope of regulation. By creating an evolving financial monitoring framework, regulatory agencies can bring these new instruments and institutions into view and, as necessary, under the regulatory umbrella. In particular, this monitoring system may limit the creation of unregulated intermediaries that pose systemic risk and whose rescue might become necessary in a financial crisis. For example, if an investment vehicle has assets that carry systemic risk (identifiable by covariance and possibly excess return) and short-term liabilities (e.g., AA commercial paper), then the investment vehicle prima facie is liable to runs and may transmit systemic risk to regulated entities if those regulated entities provide back-up lines of credit and/or credit risk insurance (Acharya and Richardson 2009). If the new combination of instruments reduces capital requirements, then capital requirements for the new entities may need to be increased. Another valuable step would be to require that whenever risk is removed from a regulated financial institution's balance sheet, that institution should be responsible for informing the systemic regulator of the counterparty that has taken on the risk. Such notification could have revealed to regulators the buildup of systemic risk at AIG's United Kingdom offices.

One concern about setting up a financial regulatory database is the increasingly global nature of finance. Debts originated in one country can

6. In taking advantage of these information asymmetries, the agents may not be aware that they are not acting in the interests of the principals. As we shall see, agents who took advantage of the apparent gains from holding "economic catastrophe" bonds may have thought they were simply doing efficient arbitrage between mispriced instruments. 
be held on the other side of the world. Can we keep track of enough US financial assets to make a difference, beginning with US financial borrowings? Fortunately, the US financial structure is unusual in that a substantial proportion of US financial liabilities are held abroad (15 percent, 2008 year end), but only a relatively small proportion of US financial assets are owed by the rest of the world (4 percent, 2008). As seen in table 3.1, of the $\$ 35.4$ trillion owed by the nonfinancial sector, only $\$ 1.9$ trillion is owed by foreigners. Thus, most of the nonfinancial holdings of the US financial system can be understood based on microdata from US entities. This means that as a first approximation, financial instruments originating in the United States would be a reasonable starting point for understanding US nonfinancial risks. It would be of value, of course, if other countries carried out similar efforts to expand this macro-micro database across the globe. Other countries' financial regulatory databases can perhaps be more easily built once the US financial regulatory database is in place.

\subsection{Drilling beneath the Flow of Funds Accounts to the Microdatabase}

We envision a microdatabase that is attached to the Flow of Funds Accounts and its satellite accounts. Ideally, clicking on a given cell in the Flow of Funds Macro Accounts would reveal the underlying microdata that are used to create the aggregate, as well as databases linked to this primary sampling data. The Flow of Funds section of the Federal Reserve has already developed a prototype system for showing the data source for all the cells of the Flow of Funds Accounts. As these data sources themselves are typically based on microdata surveys, this is a first step in the direction we envision.

The microdata part of the database could be built up with existing databases, including existing academic, government, and commercial databases (e.g., CRSP, Compustat, LoanPerformance, Equifax, call reports, HMDA, Quarterly Terms of Bank Lending, Shared National Credit, Census, IRS, Fannie Mae and Freddie Mac), and data from existing depositories, exchanges, and registries (e.g., Depository Trust and Clearing Corporation, Federal Reserve Depository).

These databases collectively show that it is feasible to collect data and to aggregate them along a variety of dimensions. For existing databases, as argued above, each could be mapped to corresponding entries in the Flow of Funds Accounts. ${ }^{7}$ For example, a microdata set of credit bureau data on households could be viewed as a sample of the universe of households, and the entries used to estimate the universe. The estimate of total mortgages could then be compared against the estimate of total mortgage borrowing by households in the Flow of Funds. Doing this across data sets will result

7. Begenau, Piazzesi, and Schneider (2014) discuss performing this mapping as well as concrete measures that can be used to summarize the microdata. 
in a more reliable aggregate estimate of household mortgage borrowing and will allow researchers and decision makers to see relatively transparently how representative a given microdata set is and, therefore, how trustworthy results from analysis of the microdata are likely to be.

Record Linkage. A key improvement to these databases could be automated record linkage. The econometric studies discussed in section 3.2 rely on the econometrician's ability to track instruments and agents across data sets and over time, known generically as record linkage. There are now relatively standard computational techniques for optimizing record linkage (Herzog, Scheuren, and Winkler 2007), but these techniques have not been used in economic and financial studies.

For example, a mortgage origination in a credit bureau's data on a given household will permit the identification of other mortgages held by the same household, and thus may help to reveal the possibility that the home is actually a speculative investment and therefore its mortgage is not for an owneroccupied residence. However, to follow the ongoing current loan-to-value ratio of the mortgage, a key element in the evaluation of the credit risk of the mortgage, requires knowing the location of the home and home price inflation at that location since purchase, with a link to the local home price index. Depending on the regulator's concerns, it may be useful to know the broker, the appraisal value, the interest rate on the mortgage, the originator, whether the mortgage is held in portfolio or securitized, and the servicer. Each of these may be available from a different data set or within the same data set at a different point in time. Establishing procedures to automate these linkages would be of value to regulators and would facilitate new and updated econometric analyses of risks.

If individual financial instruments are given unique identifiers so that they can be linked from data set to data set, that would clearly facilitate cross-checks in financial monitoring. The CUSIP numbers (the American Bankers Association numbering system) perform this service for many financial instruments. A consistent form of instrument identification would be of aid to the financial industry itself, which would be better able to merge portfolios (as a consequence of mergers and acquisitions) while retaining a deep understanding of their characteristics. Linking permanent identifiers to financial instrument characteristics will facilitate bottom-up analysis of portfolios and permit complex stress test simulations. Establishment of a set of unique identifiers has apparently been hampered by coordination issues; in this situation, regulators can take a strong stance in favor of implementation and benefit both regulation and private parties.

All financial instruments that represent direct claims against nonfinancial institutions - firms, households, or other legal entities such as governments - could be registered, provided with a unique identifier, and accompanied by summary data on its characteristics, such as its legal form, the issuer or debtor, type of debt or equity, and so forth. These financial instruments 
are the fundamental financial instruments; their provision is an important rationale for concern about systemic risk. The summary data could be coded in a uniform system, following the experience of database providers and depositories. The American Securitization Forum's ASF LINC (Loan Identification Number Code) is a mechanism that seeks to provide unique identifiers for mortgages, credit cards, auto loans, and other retail debt. These unique identifiers would be linked to a database that would have characteristics of the instrument. The Enterprise Data Management Council, with the support of the financial industry and data management firms, has taken important steps toward developing a system that codes a wide variety of financial instruments, fundamental and otherwise.

A crucial step is to see where microdata are not yet available; in particular, it would be valuable to map out areas where the Flow of Funds aggregate data rely on estimates or where the underlying data are inadequately reported. For example, repo data are reported on a net basis rather than on a gross basis (Eichner, Kohn, and Palumbo, chapter 2).

To provide more transparency, it would be desirable to map the microdata geographically, to the extent possible. In the absence of unique identifiers and with data where identities of lender and borrower have been scrubbed, much can still be learned by associating microdata geographically. It is often possible for data managers to match, say, mortgage performance to credit ratings across data sets while maintaining anonymity of the underlying individuals. Even if that is not the goal or not possible, missing data (such as income in credit bureau data) can be usefully estimated using geography together with geocoded census information. To the extent that geocoded microdata can be obtained, this information provides a more detailed crosscheck on the accuracy and quality of data.

Measures of the quality of the data, both for aggregate estimates and for the microdata, could be integrated into metadata provided as a standard feature of the database. Quarterly vintages of the data, once vetted, could be archived, to create a real-time database.

One efficient form for gathering microdata is presented by the US Survey of Terms of Bank Lending, a quarterly survey that collects information on all loans granted by the surveyed banks in the first week in the middle month of each quarter. The survey draws voluntary responses on 30 to 40 thousand loans from 648 banks and, according to the Office of Management and Budget's Information Collection Review, requires 6,840 annual burden hours from respondents. (A limitation of this survey is that it collects information on loans only at origination and does not follow them over time.) Another efficient alternative may be to have a third-party registry collect data on financial instruments as the Depository Trust and Clearing Corporation does. Third-party vendors are also efficient providers of data; servicer data - for example, the First American LoanPerformance mortgage and home equity loan data sets - are another efficient way to collect data. 
It should also be noted that sampled loan data are routinely used as part of bank examinations in the United States; the systematic compilation of loan data may impose little additional burden on banks.

An interesting pioneering step has been taken by the Sveriges Riksbank, the Swedish central bank, in collecting microdata on loans at Swedish banks together with credit bureau information. This data collection is discussed in Jacobson, Linde, and Roszbach (2006). Nakamura and Roszbach (2010) provide a methodology for comparing the quality of bank loan ratings to credit bureau ratings using this data set.

Another valuable and efficient regulatory data set is the US Shared National Credit. This covers all syndicated loans and loan commitments of more than $\$ 20$ million that are shared pro rata across three or more unaffiliated federally supervised institutions - in all, \$2.9 trillion in committed funds as of the end of 2009. This data set includes all the institutions holding the loans and the internal loan ratings of the supervised institutions. As Avery et al. (2014) demonstrate, the data can be used to evaluate the quality of bank loan monitoring and thus is a valuable adjunct to bank examination. Moreover, syndicated loans are risks that are shared across financial institutions and thereby provide direct estimates of systemic risk factors.

Derivative securities, including derivatives, options, exchange-traded funds, asset-backed securities, and the like should be provided with unique identifiers and accompanied with summary data on the fundamental financial instruments to which the derivative security is linked. As mentioned before, the Enterprise Data Management Council has been taking important steps in developing methodologies and semantics for these tasks.

Some difficult questions arise from intellectual property in databases and in unique identifiers. Private third-party collection of databases is an efficient method of collecting and organizing data. These databases, moreover, have the advantage of having already been created, so that their creation is a sunk cost and their profitability makes it likely that the data will be collected moving forward. However, such data have drawbacks as well. First, the databases are expensive, and regulatory use of the data, by validating them, may make them more valuable. Second, key attributes of the data-such as the entity providing the data - may not be available to the users of the database as a condition of the entity's participation. Third, the licenses to use the databases that are purchased typically come with restrictions on how the data may be used and shared. If regulators are to view these third-party vendors as providing a conduit by which a regulated entity fulfills part of its datareporting requirements, then it would appear natural that some of these license restrictions should be annulled. And the databases could be required to be made available to the regulator on a marginal cost basis.

Regulated financial institutions that hold, acquire, or sell financial instruments or derivatives as assets could be required to ensure that the financial monitor is provided with quarterly information on the current holder of 
these assets and the current status of the instrument. Fulfilling this requirement would be facilitated by the use of depositories and exchanges. As time passes, the data received quarterly will become a historical microdatabase.

\subsection{Access to the Data}

Access to the microdata supporting the financial monitoring database would be made available to the staff of the financial monitor and to other regulators. It might also be made available to academic and government specialists who wish to use the data to make studies of risk characteristics of the instruments and of the holders of the instruments. Such studies would be made public, with public data screened for confidentiality, and would also be made available to financial regulators.

An academic advisory board composed of leading financial and economic professors and researchers could be established to advise the financial monitor and the regulatory community about the advisability of extensions to data collection and of extensions of regulation to additional institutions that are potential sources of systemic risk.

The academic advisory board could also designate studies to be conducted to measure alternative aspects of systemic risk. This would naturally be accompanied by open access of the database (conditional on strict confidentiality) to academic researchers who wish to investigate questions related to systemic risk. Finally, the systemic regulator could have a substantial research department of economic and finance researchers of the highest academic quality. This research department could devote most of its time to frontier research on finance and economics and also conduct policy studies on systemic risk. Having access to the database will help the research department attract top researchers.

These researchers would, as a byproduct of their research, analyze the quality of the data being supplied by regulated financial intermediaries and other data providers. It might be useful for the database office or the analytical group to have the authority and the responsibility to monitor the quality of the data. The systemic regulator and other regulators could be empowered to require that regulated financial intermediaries maintain high-quality data. This would help ensure that regulators and internal risk managers have access to the information they need to provide high-quality analysis.

\subsection{Summary}

I have discussed how to assemble and maintain a database of financial instruments and derivatives with both macro- and microcomponents. Such a database would have been of material aid to regulators and to financial institutions in measuring the accumulating risks that led up to the financial crisis of 2007-2009, and it would be designed to be of aid in enabling regulators to anticipate and mitigate future financial crises. 
The US Office of Financial Research will have the authority to obtain data from financial institutions. An important element of this would be requiring that individual financial instruments and institutions have unique identifiers linked to machine-readable contract characteristics. The office could be responsible for establishing quality standards for the data obtained and would advise financial institution supervisors when institutions were failing to live up to those standards. It would be desirable from the standpoint of monitoring systemic risk to establish readily usable links across these data sets, a process that would be facilitated by efforts currently underway to standardize identifiers for instruments and entities, and to provide machinereadable contractual terms. It would also be useful in the long run to establish data links and methods to create accessible archival data that could be accessed from multiple secure data centers.

\section{References}

Acharya, Viral V. 2014. "A Transparency Standard for Derivatives.” In Risk Topography: Systemic Risk and Macro Modeling, edited by Markus K. Brunnermeier and Arvind Krishnamurthy. Chicago: University of Chicago Press.

Acharya, Viral V., and Matthew Richardson, eds. 2009. Restoring Financial Stability: How to Repair a Failed System. New York: NYU Stern School of Business.

Adrian, Tobias, Brian Begalle, Adam Copeland, and Antoine Martin. 2014. "Repo and Securities Lending." In Risk Topography: Systemic Risk and Macro Modeling, edited by Markus K. Brunnermeier and Arvind Krishnamurthy. Chicago: University of Chicago Press.

Avery, Robert, Lewis Gaul, Leonard Nakamura, and Douglas Robertson. 2014. "Measuring the Quality of Bank Loan Monitoring: Evidence from US Syndicated Loans." Working Paper, Federal Reserve Bank of Philadelphia.

Begenau, Juliane, Monika Piazzesi, and Martin Schneider. 2014. "Remapping the Flow of Funds." In Risk Topography: Systemic Risk and Macro Modeling, edited by Markus K. Brunnermeier and Arvind Krishnamurthy. Chicago: University of Chicago Press.

Bond, Charlotte Ann, Teran Martin, Susan Hume McIntosh, and Charles Ian Mead. 2007. "Integrated Macroeconomic Accounts for the United States." Survey of Current Business February:14-31.

Brueckner, Jan, Paul Calem, and Leonard Nakamura. 2012. "Subprime Mortgages and the Housing Bubble." Journal of Urban Economics 71:230-43.

Cecchetti, Stephen G., Ingo Fender, and Patrick McGuire. 2010. "Toward a Global Risk Map.” BIS Working Paper no. 309, Bank for International Settlements, May.

Cho, Man, and Isaac F. Megbolugbe. 1996. "An Empirical Analysis of Property Appraisal and Mortgage Redlining." Journal of Real Estate Finance and Economics 13:45-55.

Coval, Joshua, Jakub Jurek, and Erik Stafford. 2009a. "Economic Catastrophe Bonds." American Economic Review 99:628-66.

_. 2009b. "The Economics of Structured Finance." Journal of Economic Perspectives 23:3-25.

Covitz, Daniel M., Nellie Liang, and Gustavo Suarez. 2013. "The Evolution of a 
Financial Crisis: Collapse of the Asset-Backed Commercial Paper Market." Journal of Finance 68:815-48.

Crone, Theodore M., Leonard I. Nakamura, and Richard Voith. 2010. "Rents Have Been Rising, Not Falling, in the Postwar Period." Review of Economics and Statistics 92:628-42.

Demyanyk, Yuliya, and Otto Van Hemert. 2011. "Understanding the Subprime Mortgage Crisis." Review of Financial Studies 24:1848-80.

Denison, Edward F. 1962. "Comment." In The Flow of Funds Approach to Social Accounting, Studies in Income and Wealth, vol. 26, 425-30. Princeton, NJ: Princeton University Press.

Elul, Ronel. 2009. "Securitization and Mortgage Default: Reputation vs. Adverse Selection." Federal Reserve Bank of Philadelphia Working Paper no. 09-21, September.

Engle, Robert. 2009. Anticipating Correlations: A New Paradigm for Risk Management. Princeton, NJ: Princeton University Press.

French, Kenneth, Martin N. Baily, John Y. Campbell, John H. Cochrane, Douglas W. Diamond, Darrell Duffie, Anil K. Kashyap, et al. 2010. The Squam Lake Report: Fixing the Financial System. Princeton, NJ: Princeton University Press.

Gallin, Joshua. 2008. "The Long-Run Relationship between House Prices and Rent." Real Estate Economics 36 (4): 635-58.

Garmaise, Mark. 2008. "After the Honeymoon: Relationship Dynamics between Mortgage Brokers and Banks." Working Paper, Anderson School of Management, UCLA.

Gorton, Gary B., and Andrew Metrick. 2012. "Who Ran On Repo?” NBER Working Paper no. 18455, Cambridge, MA.

Herzog, Thomas N., Fritz J. Scheuren, and William E. Winkler. 2007. Data Quality and Record Linkage Techniques. New York: Springer.

Jacobson, Tor, Jesper Linde, and Kasper Roszbach. 2006. "Internal Rating Systems, Implied Credit Risk, and the Consistency of Banks' Risk Classification Policies." Journal of Banking and Finance 30:1899-926.

Keys, Benjamin J., Tanmoy Mukherjee, Amit Seru, and Vikrant Vig. 2009. "Financial Regulation and Securitization: Evidence from Subprime Loans." Journal of Monetary Economics July:700-20.

Mendelson, Morris. 1962. "The Optimum of Grossness in the Flow-of-Funds Accounts." In The Flow of Funds Approach to Social Accounting, Studies in Income and Wealth, vol. 26, 411-25. Princeton, NJ: Princeton University Press.

Nakamura, Leonard, and Kasper Roszbach. 2010. "Credit Rating and Bank Monitoring Ability.” Federal Reserve Bank of Philadelphia Working Paper no. 10-21, May.

Teplin, Albert, Rochelle Antoniewicz, Susan Hume McIntosh, Michael Palumbo, Genevieve Solomon, Charles Ian Mead, Karin Moses, and Brent Moulton. 2006. "Integrated Macroeconomic Accounts for the United States: Draft SNA-USA." In A New Architecture for the US National Accounts, Studies in Income and Wealth, vol. 66, edited by Dale Jorgenson, J. Steven Landefeld, and William Nordhaus, 471-539. Chicago: University of Chicago Press.

Yamashita, Takashi. 2013. "A Guide to the Integrated Macroeconomic Accounts." Survey of Current Business 93 (April): 12-27. 